\title{
Biobriquettes-an Alternative Fuel for Sustainable Development
}

\author{
Ramesh Man Singh ${ }^{1}$, Hee-Joon Kim ${ }^{2}$, Mitsushi Kamide ${ }^{3}$ and Toran Sharma ${ }^{4}$ \\ ${ }^{1}$ Nepal Academy of Science and Technology, GPO Box 3323, Khumaltar, Lalitpur, Nepal \\ ${ }^{2}$ Toyohashi University of Technology, Tempaku-cho, Toyohashi, 441-8580, Aichi, Japan \\ ${ }^{3}$ Hokkaido Industrial Research Institute (HIRI), Sapporo, Hokkaido, Japan \\ ${ }^{4}$ Nepal Environmental and Scientific Support service ((NESS), Thapathali, Kathmandu
}

\begin{abstract}
Raw coal is still burnt as fuel in many developing countries. These also have a lot of waste biomass, which finds limited use or used inefficiently. Besides pollution from coal and biomass combustion, they always face problems during transportation and storage because they are susceptible to moisture. Biobriquettes are composite fuel prepared from a mixture of biomass and coal in a roller press briquetting machine. They consist of different proportions of biomass (up to 30\%) and coal or lignite (up to 70\%). Introduction of lime based desulfurizing agents (DSA) such as $\mathrm{CaCO}_{3}$ and $\mathrm{Ca}(\mathrm{OH})_{2}$ into the briquettes can reduce the $\mathrm{SO}_{2}$ emissions by $80-90 \%$, thus minimizing the pollution coming from coal combustion. Some fuel and combustion properties of these briquettes were studied. The briquette fuels have better physico-mechanical properties and combustion properties in comparison to coal/lignite. The ignition temperatures of biobriquettes are lower than coal or lignite, whereas the calorific values are greater than biomass. Hence, the biobriquettes can be used as an alternative fuel to fuel wood, coal and lignite in the kilns, boilers, combustors and for cooking as well.
\end{abstract}

Key words - coal, biomass, biobriquettes, desulfurizing agents, ignition temperature

\section{Introduction}

Large quantity of coal is used in many developing countries as the major fuel in industries and power generation. On one hand developing countries are burning raw coal with high sulfur content to fulfill their energy demands; on the other hand they have not been able to utilize a lot of agro- as well as forestwaste efficiently. Combustion of raw coal and other biomass fuels emit harmful emissions such as Sulfur dioxide $\left(\mathrm{SO}_{2}\right)$ and Nitrogen oxides $\left(\mathrm{NO}_{\mathrm{X}}\right)$, which are the main causes of environmental pollution such as acid rain, global warming and climate change ( $\mathrm{Lu}$ et al. 1995, Kim et al. 2002, Xu et al. 2000). Industrial boilers, furnaces and kilns in South Asia, including Nepal also use coal as the major fuel along with fuel wood, agro/forest wastes (rice husk, saw dust, etc). Particularly, the brick kilns use a wide variety of fuels such as coal, lignite, fuel wood, agro/forest residues, rubber tires, waste plastics, etc. Recent and earlier studies have revealed that these pollutants have a harmful impact on health, causing respiratory and lung diseases among people (Best et al. 1993, Tuladhar et al. 2002). Furthermore, extensive exploitation of fuel wood cause serious natural disasters such as deforestation, soil erosion, floods, land slides, etc. Hence, it is important to find substitutes for coal and fuel wood to check the pollution from coal combustion and excessive use of fuel wood.

Biobriquettes as a composite fuel to address these problems were studied and suggested as a better alternative to raw coal (Lu et al. 1998). They also reported that lime based products have good desulfurizing properties in coal as well as biobriquettes. Also biobriquettes have better combustion and fuel characteristics than coal and can be used as a substitute for coal or fuel wood. Biobriquettes were first introduced in Nepal through a joint research project "National Research and Development Centre for Alternative Energy" during 1992-1995. The project worked on developing 
biobriquettes based on locally available coal, lignite, different waste biomasses using high pressure compression technology (Singh et al. 1996). Different residual biomass (up to $30 \%$ by wt) was blended with low grade coal to get biobriquettes, which were tested for cooking purposes. The biobriquettes were found superior to fuel wood or animal dung and comparable to LPG in the cooking tests (Singh et al.1997, 2001). These products had better fuel and combustion properties than coal or lignite but could not be promoted widely. Thy ewer made using high pressure briquetting technology.

High pressure briquetting technologies are costly in comparison to low pressure technology. Low pressure techniques are much economical, technically simple and sound (Bhattacharya \& Shrestha 1990). An experimental-cum-demonstration roller press briquette production unit was set up under the Institute of Himalayan Conservation, Japan (IHCJ) and King Mahendra Trust for Nature Conservation (KMTNC) through a Biobriquetting project to use the low-pressure roller press briquetting process to produce biobriquettes of different composition using local residual biomass such pine needles, pine cones, Banmara, saw dust and coal (Indian as well as Nepalese). The physico-chemical properties of the raw materials, combustion characteristics, emissions tests and desulfurization of biobriquettes were studied in this research work.

\section{Materials and Methods}

Two types of Indian coal (Assam-A), (Bihar-B) and four Nepali coals (Dang-D), (Abidhara-Ab), (Ajimara $\mathrm{Aj}$ ), (Lignite-L) were used in this study. Besides, these saw dust, Banmara (Crofton weed, Eupatorium adenophorum) and different biomass waste were also used. Chemical grade lime based products were used as additives. Proximate and ultimate analysis of the raw materials and briquettes were conducted according to Japan Industrial Standards (JIS), JIS 8813. The calorific values were determined as per JIS 8814. In this study combustion tests were conducted to understand the combustion characteristics of the briquette fuels. The flue gas was analyzed to study the emission characteristics of $\mathrm{NO}_{\mathrm{X}}$ and $\mathrm{SO}_{2}$. Chemical grade lime based products were used as desulfurizing agent (DSA) in briquettes during the briquetting process to capture $\mathrm{SO}_{2}$.

Biobriquettes weighing $5 \mathrm{~g}$ were prepared from different biomass, coal and desulfurizing agent in a stainless steel mould using a Shimazu hydraulic press.

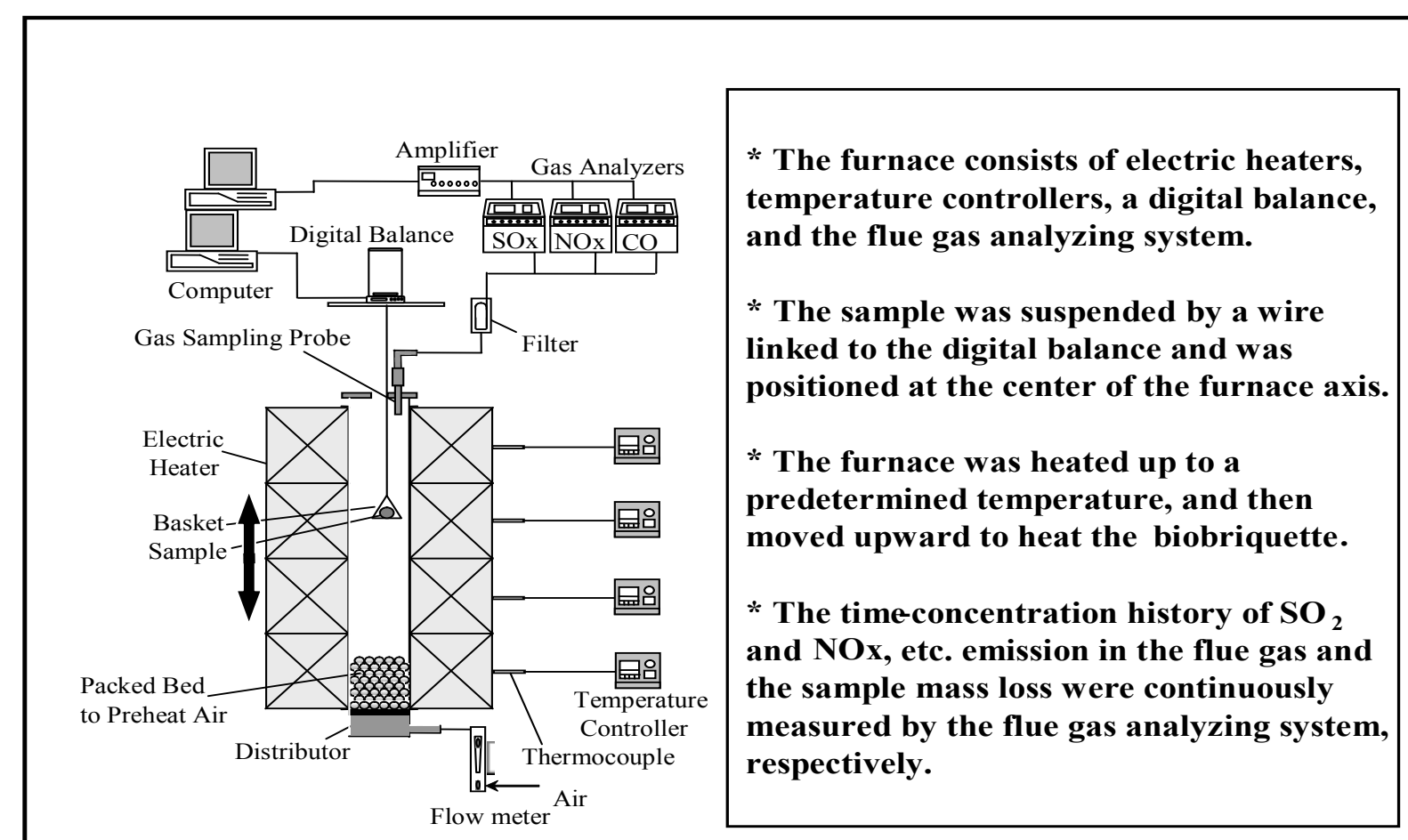

Fig. 1 Experimental Apparatus 
The combustion and desulfurization processes of briquettes were studied in vertically integrated experimental furnace shown in Fig. 1. Biobriquettes for test and demonstration were produced using a low pressure roller press briquetting machine with different mixtures of biomass coal and additives. The schematic production diagram is shown in Fig. 2 whereas the actual production is shown in Fig. 3. Biomass and coal which were ground separately and mixed with additives (DSA and binder) was loaded into the roller press briquetting machine through the feeder as indicated in Fig. 2. The mixture was pressed between the two rollers rotating in opposite direction to get pillow shaped biobriquettes. Biobriquettes of different composition for tests and demonstration shown in Fig. 4 were packed and made ready for use. These biobriquettes were tested in the mountainous areas for cooking, space heating and other purposes.

The experimental apparatus (Fig.1) consists of an electrically heated batch furnace, temperature controllers, a digital balance and a flue gas analyzing system. The sample of biobriquette is placed in a basket, which is linked with the upper digital balance, and is positioned in the center of the furnace along the vertical axis. The injected air is preheated to a desired temperature by a packed bed of alumina balls located at the bottom of the furnace. The change in the mass of biobriquette and the change in the concentration of $\mathrm{SO}_{2}, \mathrm{NO}_{\mathrm{x}}, \mathrm{CO}, \mathrm{CO}_{2}$ and $\mathrm{O}_{2}$ in the flue gas were continuously measured during the combustion process, by the digital balance and the flue gas analyzing system respectively. At the beginning of combustion, the electrical furnace is heated to a determined temperature and then is moved upward to heat the sample. The concentration of $\mathrm{SO}_{2}$ and $\mathrm{NO}_{\mathrm{x}}$, mass loss of samples verses time were continuously measured by the computer aided flue gas analyzing system and digital balance respectively. The air supply was maintained at $101 / \mathrm{min}$. The desulfurization was studied by adding DSA from $\mathrm{Ca} /$ $\mathrm{S}$ ratios $0.5-3$. The emissions of combustion were monitored and recorded using SOA-7000 $\mathrm{SO}_{2}$ analyzer of Shimazu and Horiba portable gas analyzer PH-250.

\section{Results and Discussion}

The results of the proximate and ultimate analysis of coals and biomass are given in Table 1 and 2. The high volatile matter and low fixed carbon content categorizes them into the sub- bituminous group of coals and lignite group. Assam and Dang coal has the highest sulfur contents -5.875 and $5.174 \%$ respectively. Sulfur in the biomass is very low and negligible. Ignition temperatures of all the coals are obviously higher than the biomass as they are more difficult to ignite. All of the biomass has high volatile matter content and low fixed carbon and ash content except for rice husk. This is why biomass burns with high flames whereas coals and lignite have low flames. Most of the biomass have calorific values in the range of wood or saw dust (4164 $\mathrm{kcal} / \mathrm{kg}$ ). Pine biomass has a little bit higher value which may be due to some organic oils in them.

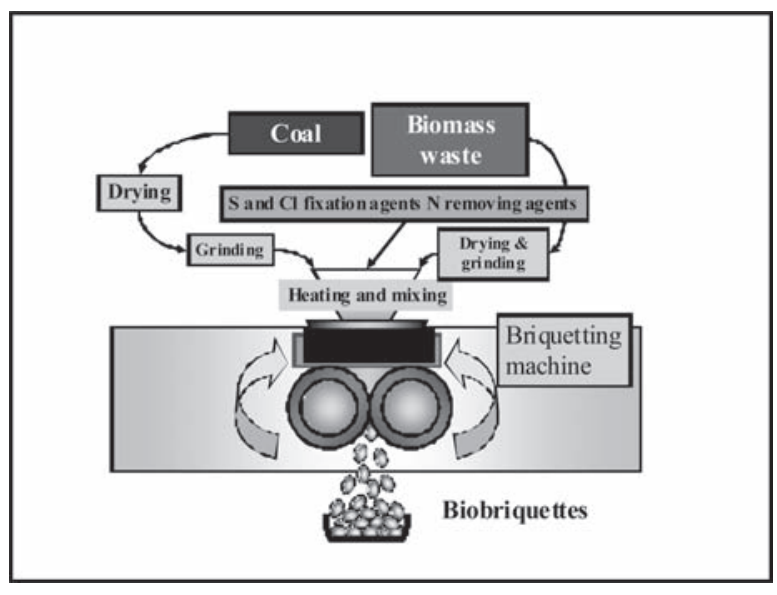

Fig. 2. Schematic diagram of biobriquettes production

Some properties of different biobriquettes (composition, calorific values and ignition temperatures, etc) based on different coals/lignite and biomasses are given in Tabl. 3 and 4. Introduction of $20 \%, 40 \%, 80 \%$ $\mathrm{BM}$ into biobriquettes causes decrease in ignition temperature by $32^{\circ} \mathrm{C}, 45^{\circ} \mathrm{C}$ and $56^{\circ} \mathrm{C}$ respectively. This means that all the biobriquettes are easier to ignite in comparison with the lignite. On the other hand when biomass is used in combination with low grade coal, the calorific values of the briquettes significantly increases with the increase of biomass content. The calorific values were calculated using the following formula:

$\mathrm{CV}$ of biobriquette $=\mathrm{CV}$ of coal $*$ mixing ratio of coal + $\mathrm{CV}$ of $\mathrm{BM} *$ mixing ratio of $\mathrm{BM}$

Calorific value of briquette is equal to the sum of calorific value of coal multiplied by the mixing ratio of coal and the colorific value of biomass multiplied by the mixing ratio of the biomass. 


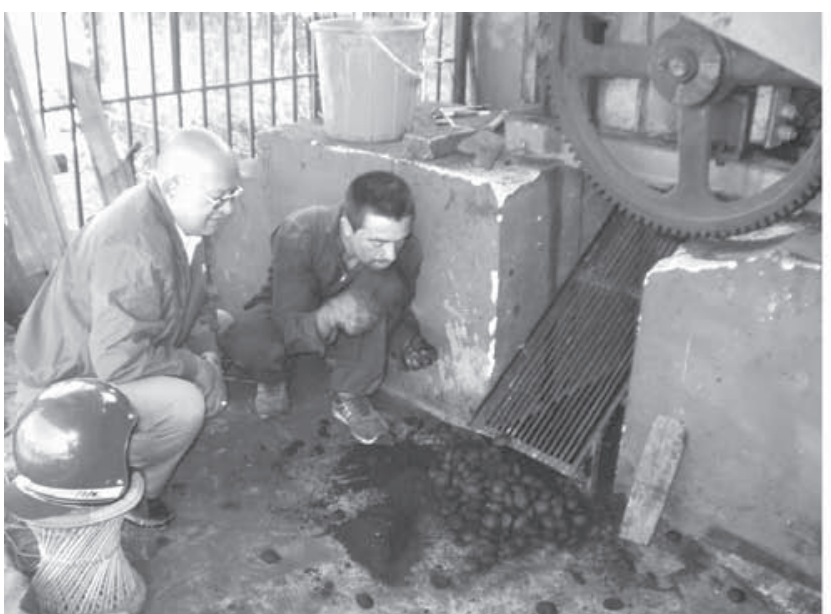

Fig. 3. Production of biobriquettes

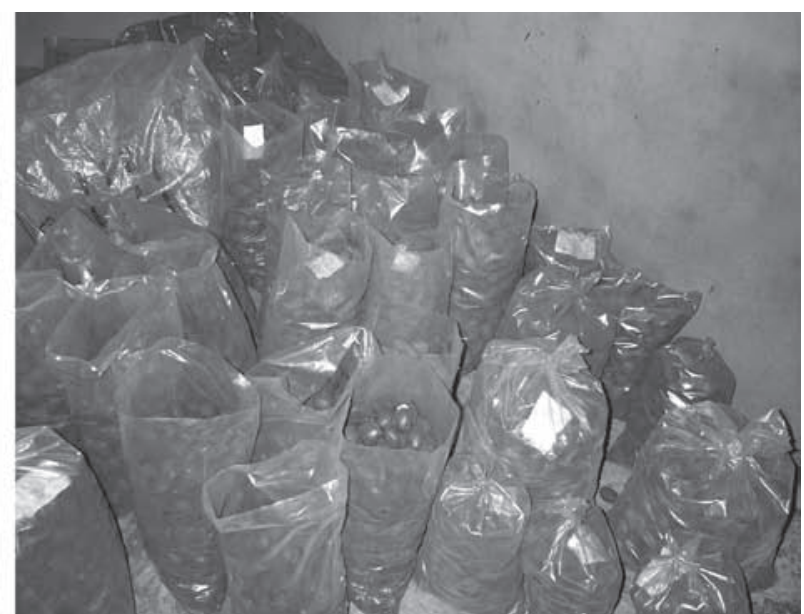

Fig. 4. Biobriquettes ready for testing

Table 1. Results of proximate and ultimate analysis of biomass raw materials

\begin{tabular}{l|l|l|l|l|l|l|l|l|l|l|l}
\hline Code & Coal name & $\begin{array}{l}\text { Fixed } \\
\text { carbon } \\
(\%)\end{array}$ & $\begin{array}{l}\text { Volatile } \\
\text { matter } \\
(\%)\end{array}$ & $\begin{array}{l}\text { Moist. } \\
(\%)\end{array}$ & $\begin{array}{l}\text { Ash } \\
(\%)\end{array}$ & $\begin{array}{l}\text { Calorific } \\
\text { value } \\
\text { Kcal/kg }\end{array}$ & N & C & S & H & $\begin{array}{l}\text { Ignition } \\
\text { temp }\end{array}$ \\
\hline PNPC & Pine needle & & & & & & & & & & \\
& Pine cone & 0.45 & $80.13-$ & $16.30-$ & $3.12-$ & 4356 & 0.845 & 45.28 & 0.074 & 6.789 & 332 \\
& & - & - & - & - & 4760 & - & - & - & - & 353 \\
BM & Banmara & 9.63 & 81.85 & 6.25 & 2.26 & 4138 & 0.225 & 44.36 & 0.073 & 6.620 & 283 \\
RH & Rice husk & 6.38 & 70.33 & 6.84 & 16.45 & 3618 & 0.367 & 38.26 & 0.038 & 5.573 & 305 \\
SD & Saw dust & 15.1 & 68.4 & 15.3 & 1.2 & 4164 & - & - & - & - & - \\
\hline
\end{tabular}

Table 2. Results of proximate and ultimate analysis of coal raw materials

\begin{tabular}{l|l|l|l|l|l|l|l|l|l|l|c}
\hline Code & $\begin{array}{l}\text { Coal } \\
\text { name }\end{array}$ & $\begin{array}{l}\text { Fixed } \\
\text { carbon } \\
(\%)\end{array}$ & $\begin{array}{l}\text { Volatile } \\
\text { matter } \\
(\%)\end{array}$ & $\begin{array}{l}\text { Moist. } \\
(\%)\end{array}$ & $\begin{array}{l}\text { Ash } \\
(\%)\end{array}$ & $\begin{array}{l}\text { Calorific } \\
\text { value } \\
\text { Kcal/kg }\end{array}$ & N & C & S & H & $\begin{array}{l}\text { Ignition } \\
\text { temp }\end{array}$ \\
\hline A & Assam & 44.37 & 36.38 & 2.02 & 17.23 & 6327 & 0.647 & 63.94 & 5.875 & 4.84 & 369 \\
$\mathrm{~B}$ & Bihar & 45.20 & 35.57 & 4.60 & 14.63 & 6495 & 1.265 & 66.48 & 1.586 & 4.910 & 359 \\
$\mathrm{D}$ & Dang & 47.28 & 27.15 & 1.13 & 24.44 & 6238 & 0.964 & 61.88 & 5.174 & 4.134 & 414 \\
$\mathrm{Aj}$ & Ajimara & 20.22 & 16.30 & 0.81 & 62.67 & - & 0.411 & 23.57 & 3.838 & 2.430 & 495 \\
$\mathrm{AB}$ & Abidhara & 14.41 & 15.93 & 1.98 & 67.69 & 1767 & 0.309 & 20.20 & 1.085 & 1.501 & 491 \\
$\mathrm{~L}$ & Lignite & 12.73 & 38.82 & - & 48.45 & 1673 & 0.89 & 29.6 & 0.51 & 2.96 & 340 \\
\hline
\end{tabular}

Table 3. Properties of biobriquettes from Banmara and lignite

\begin{tabular}{l|l|l|l|l|l}
\hline No. & Raw materials & $\begin{array}{l}\text { Briquette } \\
\text { comp (\%) }\end{array}$ & $\begin{array}{l}\text { Calorific } \\
\text { value }(\mathrm{CV})\end{array}$ & $\begin{array}{l}\text { Ignition } \\
\text { Temp }\left({ }^{\circ} \mathrm{C}\right)\end{array}$ & $\begin{array}{l}\text { Decrease in } \\
\text { Ign temp }\end{array}$ \\
\hline 1. & Banmara(BM) & 100 & 4138 & 283 & - \\
2. & Lignite(L) & 100 & 1673 & 340 & - \\
3. & LMB20 & $20 \% \mathrm{BM}$ & $2166^{*}$ & 308 & Decrease $32^{\circ} \mathrm{C}$ \\
4. & LBM40 & $40 \% \mathrm{BM}$ & $2659^{*}$ & 295 & Decrease $45^{\circ} \mathrm{C}$ \\
5. & LBM80 & $80 \% \mathrm{BM}$ & $3645^{*}$ & 284 & Decrease $56^{\circ} \mathrm{C}$ \\
\hline
\end{tabular}

$\mathrm{CV}^{*}$ calculated value 
The calorific value of LBM80 briquette reaches $3645 \mathrm{kcal} / \mathrm{kg}$ which is far higher than lignite $(1673 \mathrm{kcal} /$ $\mathrm{kg}$ ). These two factors are very positive for the utilization of the large amount of lignite and low grade coal resources in Nepal with different waste biomass. Similarly, Fig. 5 also shows similar results of decrease in ignition temperatures for biobriquettes based on low grade Ajimara coal and waste biomass pine needles.

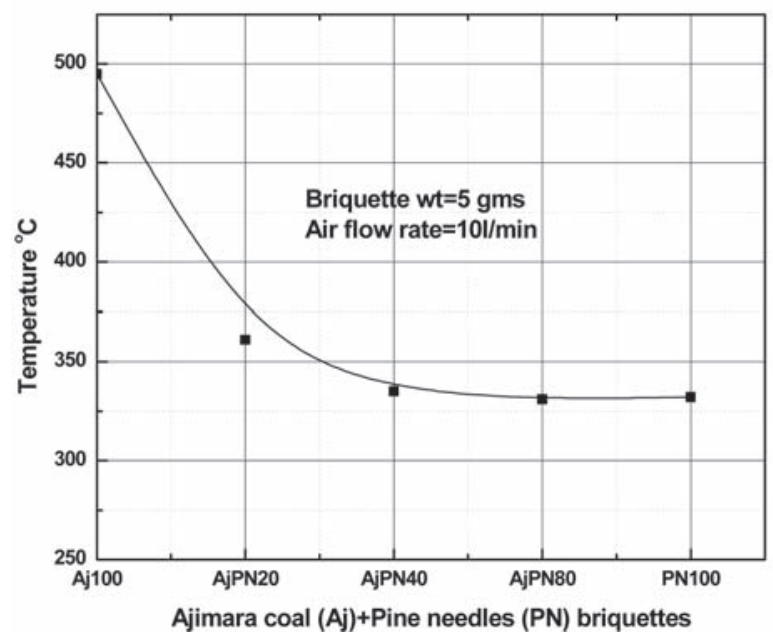

Fig. 5. Ignition temperature verses different compositions of biobriquettes

When biomass is combined with better quality coal too the same phenomenon is observed. The $\mathrm{Cv}$ of biobriquette increases in comparison with the biomass briquette (Table 3). Biobriquettes containing 20\% BM $(\mathrm{Cv}=4138 \mathrm{kcal} / \mathrm{kg})$ each in combination with three different coals Abidhara, Assam and Dang have calorific values of 2240,5889 and $5818 \mathrm{kcal} / \mathrm{kg}$. The calorific values for the respective coals are 1767, 6327 and 6238 $\mathrm{kcal} / \mathrm{kg}$. In case of low grade Abidhara coal the calorific value increase from 1767 to 2240 , whereas for other coals the values are to 5889 and $5818 \mathrm{kcal} / \mathrm{kg}$ respectively.

On the other hand these types of coals have higher sulfur content, hence, it is necessary to capture the $\mathrm{SO}_{2}$ liberated during combustion. Calcium hydroxide was used in all cases and the desulfurization efficiency is given the Table 4 . For most of the cases more than $80 \%$ of the $\mathrm{SO}_{2}$ released can be captured during the combustion. In some cases it is more 90, 92, and 93\%. To quantitatively compare the desulfurization process, the definition of desulfurization efficiency (Lu et al. 1998) is introduced as

$$
\eta_{S O 2}=1-S O_{2(\mathrm{Ca} / \mathrm{S}=n)} / S O_{2(\mathrm{Ca} / \mathrm{S}=0)} \quad \text { Where, }
$$

$\eta_{S O 2}$ is the desulfurization efficiency, $\mathrm{SO}_{2}(\mathrm{Ca} / \mathrm{S}=0)$ is the $\mathrm{SO}_{2}$ emission from the coal briquette combustion without any limestone and $\mathrm{SO}_{2}(\mathrm{Ca} / \mathrm{S}=\mathrm{n})$ is $\mathrm{SO}_{2}$ emission with addition of desulfurizing agent. $\mathrm{Ca} / \mathrm{S}$ in the equation represents the molar ratio of calcium to sulfur. It is clear

from the formula that $\eta_{\mathrm{SO} 2}$ shows the decrease of $\mathrm{SO}_{2}$ emission in briquettes using DSA with respect to $\mathrm{SO}_{2}$ emission without DSA. Desulfurization curves for Dang and Assam coals with $20 \%$ Banmara biomass are given in Fig. 6. They are 92 and $82 \%$ respectively.

\begin{tabular}{|c|c|c|c|c|c|c|}
\hline No & Material & $\begin{array}{l}\text { Briquette } \\
\text { composition }\end{array}$ & $\begin{array}{l}\text { Sulfur } \\
\text { content (S) } \\
(\mathrm{wt} \%)\end{array}$ & $\begin{array}{l}\text { Desulfurisation } \\
\text { with } \mathrm{Ca}(\mathrm{OH}) 2 \\
(\%)\end{array}$ & $\begin{array}{l}\text { DS of white } \\
\text { coal }(\%)\end{array}$ & $\begin{array}{l}\text { Calorific } \\
\text { value }(\mathrm{CV}) \\
(\mathrm{kcal} / \mathrm{kg})\end{array}$ \\
\hline 1. & Banmara (BM) & 100 & Negligible & _- & - & 4138 \\
\hline 2. & Abhidara (Ab) & 100 & 1.085 & 92 & 98 & 1767 \\
\hline 3. & Assam (a) & 100 & 5.875 & 77 & 88 & 6327 \\
\hline 4. & Dang (D) & 100 & 5.174 & 88 & 94 & 6238 \\
\hline 5. & AbBM20 & $20 \% \mathrm{BM}$ & $<1.085$ & 93 & 95 & $2240 *$ \\
\hline 6. & ABM20 & $20 \% \mathrm{BM}$ & $<5.875$ & 79 & 84 & $5889^{*}$ \\
\hline 7. & DBM20 & $20 \% \mathrm{BM}$ & $<5.174$ & 90 & 93 & $5818^{*}$ \\
\hline & $\begin{array}{l}\text { CB1 (Assam coal } \\
\text { used) }\end{array}$ & $90 \%$ A coal $+10 \% \mathrm{SD}+15 \%$ Bentonite & $<5.875$ & $\begin{array}{l}88 \%[1 \mathrm{~g} \mathrm{Ca} \\
(\mathrm{OH}) 2]\end{array}$ & - & $6111^{*}$ \\
\hline 9. & $\begin{array}{l}\text { CB2 (Assam coal } \\
\text { used) }\end{array}$ & $80 \%$ A coal $+20 \% \mathrm{SD}+10 \%$ Bentonite & $<5.875$ & $\begin{array}{l}88 \%[1 \mathrm{~g} \\
\mathrm{Ca}(\mathrm{OH}) 2\end{array}$ & & $5893^{*}$ \\
\hline 10. & $\begin{array}{l}\text { CB3 (Assam coal } \\
\text { used) }\end{array}$ & $80 \%$ A coal $+20 \% \mathrm{SD}+10 \%$ Bentonite & $<5.875$ & $\begin{array}{l}86 \%[1 \mathrm{~g} \\
\mathrm{Ca}(\mathrm{OH}) 2]\end{array}$ & - & $3033 *$ \\
\hline
\end{tabular}


The ignition of the briquette fuel has been explained by the shrinking core model of burning of a briquette ball. The burning takes place at the surface layer of the briquette reducing the size of the burning ball gradually (Kim et al. 2001). Since biobriquette contain biomass particles in it, during combustion these particles release huge amount of volatile matter creating pores in biobriquettes. Thus, diffusion of $\mathrm{O}_{2}$ into the briquettes become faster due to these pores and the burning becomes more efficient and complete.

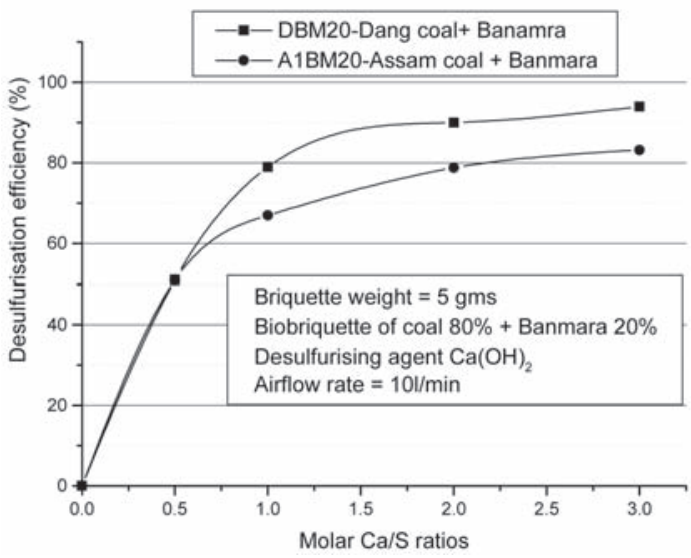

Fig. 6. Desulfurization of biobriquettes of coal and Banmara

Besides the tests performed on the above mentioned model biobriquettes some actual samples of briquettes for use in field tests and demonstration for cooking were also tested for the desulfurization. In Table 4 briquettes CB1, CB2, CB3 with different composition were obtained from the production stock shown in Fig. 4. The desulfurizing tests were performed and the $\mathrm{CV}$ was calculated. For CB1, $\mathrm{CB} 2$ and $\mathrm{CB} 3$ the desulfurization efficiency using $1 \mathrm{~g}$ $\mathrm{Ca}(\mathrm{OH})_{2}$ was $88 \%, 88 \%$ and $86 \%$ respectively (Table 4 ). The emissions and capture of the $\mathrm{SO}_{2}$ during combustion period of the briquette is illustrated in Fig. 9. The area beneath the curve shows the amount of $\mathrm{SO}_{2}$ emissions. Three curves are shown: Curve 1 without $\mathrm{Ca}(\mathrm{OH})_{2}$, Curve 2 with $0.5 \mathrm{~g} \mathrm{Ca}(\mathrm{OH})_{2}$ and Curve 3 with $1 \mathrm{~g} \mathrm{Ca}(\mathrm{OH})_{2}$. For

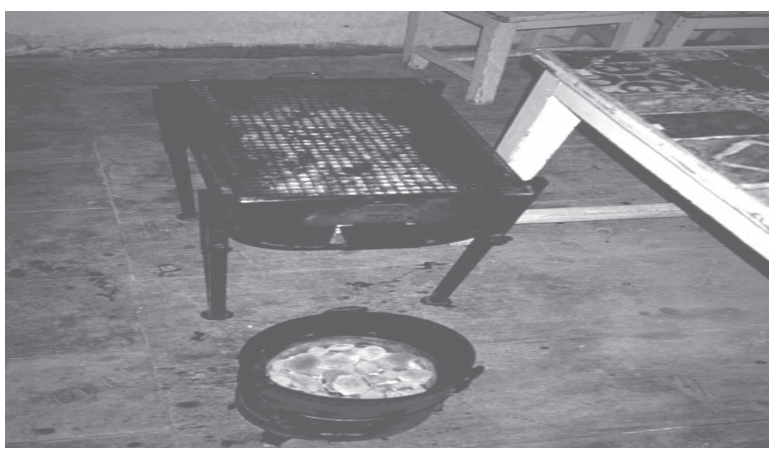

Fig. 7. Biobriquettes for spacing heating comparison white coal briquettes were prepared using some samples of coal and biobriquettes. One part of the DSA was mixed into the coal or biobriquette and another part is used to coat the surface of the biobriquette. The desulfurization efficiency using the same amount of DSA is higher when white coal or biobriquettes were used. The desulfurization efficiency reaches values up to $98 \%$. This can be seen from the values given in Table 4 . The values in column 6 are higher than the corresponding values in column 5. Hence, using biobriquette instead coal or coal briquette gives us some definite advantage in terms of combustion efficiency, ignition temperature, heat values and low emissions of $\mathrm{SO}_{2}$.

Many developing countries are facing environmental problems from the combustion of low grade coal with high sulfur content being used is combustors and boilers and kilns. These countries also use a lot of fuel wood as the main source of energy. Shifting slowly from raw coal to biobriquettes could not only solve to some extent the environmental problem but also utilize the enormous amount of biomass residues and low grade coal within the country.

Cooking tests and demonstrations in mountainous areas are shown in Fig. 7 and 8. Biobriquettes as fuel for barbeque and cooking meals proved attractive for the mountainous tourist trekking areas of Mustang. Since these areas have cold climatic conditions during the winter they can be used indoor as fuel for space heating since harmful emissions from the coal combustion is captured by the lime based desulfurizing agents. Boiling water over the devices for cooking and drinking purposes can easily be integrated with space heating since the pollution from harmful and smoke emissions are negligible. After the successful conclusion of the project the experimental and demonstration roller press briquetting unit has currently been handed over to a private party for the production and supply of cooking fuel to the Bhutanese refugee camp in Eastern Nepal where over 100,000 refugees are located.

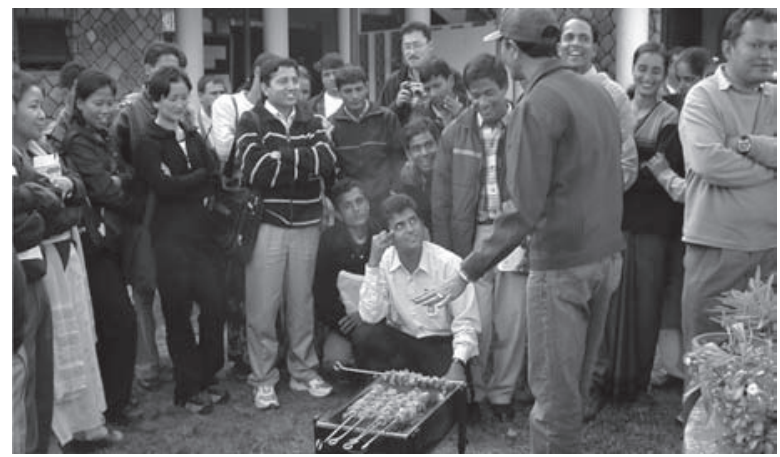

Fig. 8. Demonstration of Biobriquettes for barbeque 
With the addition of biomass biobriquettes have better fuel properties and lower ignition temperature than coal. Therefore, biobriquettes are easier to ignite. They can be successfully used for cooking as well as space heating in cold and mountainous regions. In addition, to biomass, lime based products can be used as efficient desulfurizing agent to capture the sulfur content in the coal. Hence, the harmful emissions coming from coal combustion in brick kilns and different industries can be checked by using biobriquettes. Large amounts of low quality coal, lignite and biomass residues in Nepal can be used more efficiently to produce biobriquettes and replace to some extent the fuel wood used in industrial boilers and kilns and cooking.

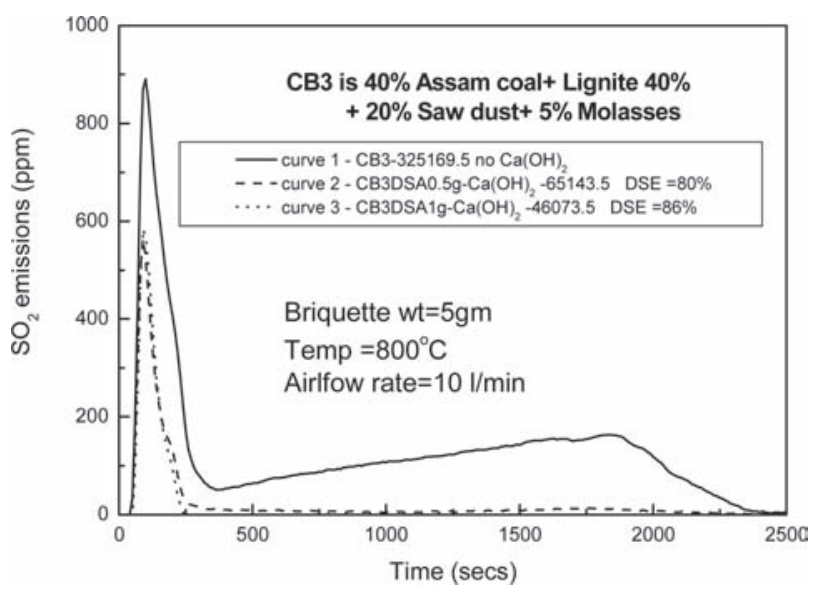

Fig. 9. Desulfurisation of $\mathrm{CB} 3$ using $\mathrm{Ca}(\mathrm{OH}) 2$ as $\mathrm{DSA}$

\section{Acknowledgement}

The authors are very grateful to the Institute for Himalayan Conservation (IHC), Japan for providing support and assistance in the research works. Thanks are also due to the Japan Society for the Promotion of Science (JSPS) for the fellowship and the Toyohashi University of Technology for the opportunity given to conduct the research.

\section{References}

Lu G., S.Y. Cheng, Y. L. Chao and B.S. Xu. 1995. Proceedings of the $3^{\text {rd }}$ international symposium on coal combustion. Beijing, China. pp. 609-616.

Xu, X., C. Chen, H. Qi, R. He, C. You and G. Xiang. 2000. Development of coal combustion pollution control for $\mathrm{SO}_{2}$ and $\mathrm{NO}_{x}$ in China. Fuel Processing Technology 62: 153-160.

Kim H, G. Lu, T. Li and M. Sadakata. 2002. Binding and desulphurization characteristics of pulp black liquor in biocoalbriquettes. Environment, Science and Technology. 36, (7): 1607-1612

Best, S. J., A. Koopmans and E. Pelink. 1993. Status and development issues of the brick industries in Asia. RWEDP FAO, United Nations, Bangkok. pp 35-50.

Tuladhar, B. and A.K. Raut. 2002. Final report on environment and health impacts of Kathmandu's brick kilns. Clean Energy Nepal (CEN), Kathmandu, Nepal: pp 6-35.

Lu G., H. Kim, J. Yuan, I. Naruse and K. Ohtake. 1998. Experimental study on self-desulfurization characteristics of biobriquette in combustion. Energy and Fuels 12 (4): 689-696.

Singh, R.M., M. Kamide and M. Toshihiko. 1996. Some chemical and physico-mechanical properties of Nepalese coal tested for biobriquettes. Journal of Nepal Chemical Society 15: 12-18.

Singh, R.M., M. Kamide and M. Toshihiko. 1997. Some chemical properties of Nepalese biomass and biobriquettes. Journal of Nepal Chemical Society 16:5-9.

Singh, R.M., M. Toshihiko, M. Kamide, K. Taniguchi and K. Deguchi. 2001. Biobriquettes-An alternative fuel for domestic and industrial applications. Nepal Journal of Science and Technology 3:105-114.

Bhattacharya S.C. and R.M. Shrestha. 1990. Biocoal technology and economics. In: Hot and high pressure densification pp 14-29, RERIC, AIT Bangkok, Thailand.

Kim H, G. Lu, I. Naruse, J. Yuan, and K. Ohtake. 2001. Journal of Energy Resources and Technology 123:27-31. 
Nepal Journal of Science and Technology 10 (2009) 